\title{
Design of Conceptual Architecture of Maintenance Medical Facilities Information Systems
}

\section{Case Study at PKU Muhammadiyah Gombong General Hospital}

\author{
Sigit Widadi ${ }^{1, *}$ Hanifah Rahmi Fajrin ${ }^{1}$
}

\author{
${ }^{1}$ Department of Medical Electronics Technology, Vocational Program, Universitas Muhammadiyah Yogyakarta \\ *Corresponding Author.Email:swdskom@umy.ac.id
}

\begin{abstract}
The management of medical facilities that have not made use of the information system (IS) has caused various difficulties for stakeholders. For the executive, the implementation of the medical facility management information system is deemed necessary to improve the quality of hospital services, while for technical personnel this step is expected as a way to facilitate work. This article presents the design of a medical facility management information system in the form of a systematic conceptual design in order to obtain an architectural illustration that is easily understood by stakeholders at the executive level. The method used in this study is to compile a business process design using the Zachman framework enterprise architecture (EA) by describing the perspective of the owner involved through a 6 x 6 matrix. The result of this research is the conformity between the context and the formulation of the concept of the medical facility maintenance business process model. If appropriate and approved, then an architectural design can be drawn up at the system modeling level from the designer's perspective.
\end{abstract}

Keywords-Zachman framework, medical means, maintenance

\section{INTRODUCTION}

PKU Muhammadiyah Gombong is one of the public hospitals belonging to the Muhammadiyah foundation in Indonesia. The hospital is located on Jl. Yos Sudarso No. 461 Tel. (0287) 473185 Gombong District, Kebumen Regency, Central Java Province, Indonesia. This institution has a medical facility maintenance unit (PSM) and public facility maintenance (PU) which is led by the Director of Clinical Service Support. The organizational structure can be seen in Figure 1.

To support the provision of information on the maintenance of medical facilities, stakeholders stated that RSU PKU Muhammadiyah Gombong needs to implement IS as needed because the procedures for managing medical facilities are different from non-medical facilities [1]. Therefore, stakeholders need to get an overview of the SI architecture.

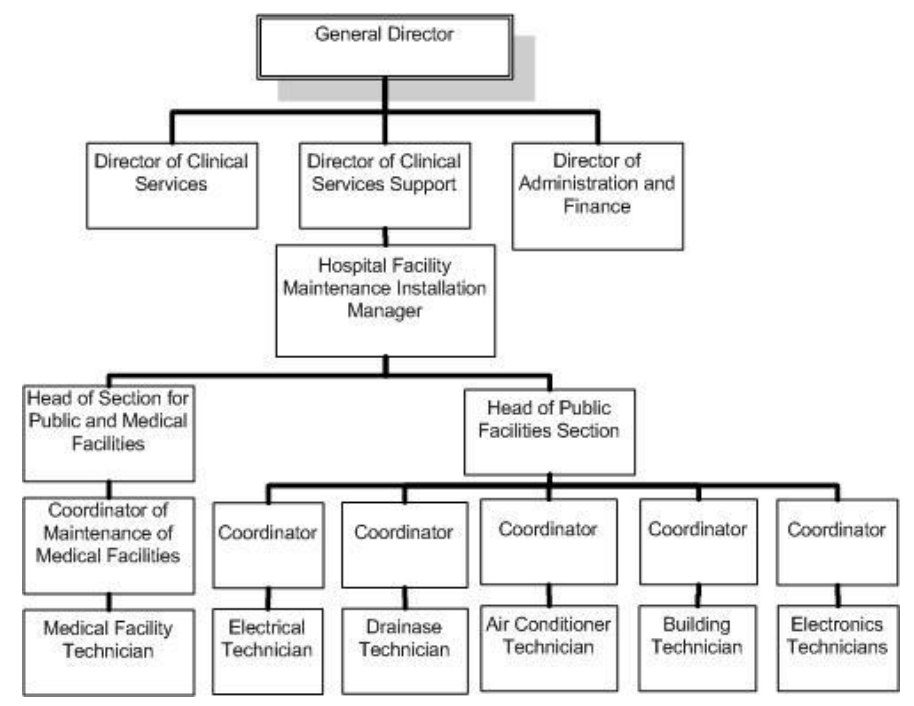

Figure 1. Organization Structure of PKU Muhammadiyah Gombong Hospital

One of the popular enterprise architecture (EA) frameworks adapted in the design of enterprise architecture planning (EAP) is the Zachman Framework [2]. This framework was chosen based on the argument that stakeholders consist of several levels who have various viewpoints and interests [3].

In principle, Zachman divides SI into three major elements, namely: Data, Process, and Technology - which 
are then developed into six main entities in the form of a $6 \times 6$ matrix [5].

1. Planning Perspective (Scope Context): Namely a list of the scope of business elements whose concepts are defined by strategists as theorists.

2. Owner's Perspective (Business Concept): A semantic model that describes the business relations between each business component that can be understood by the chief executive (owner).

3. Designer Perspective (System Logic): A more detailed logic model that contains design requirements and system limitations built by designers (architects).

4. Developer Perspective (Technology Physics): A physical model that focuses on design for specific needs within the constraints of technology, people, cost and scope of time defined by engineers as builders.

5. Implementing Perspectives (Component Assemblies): Specific technologies, on how components are assembled and operated, are configured by the technician as implementers.

6. Participant's Perspective (Operation Classes): Real functioning system events used by technicians as participants.

The Zachman concept is represented in the form of a $6 \times 6$ matrix as shown in Figure 2.

\begin{tabular}{|c|c|c|c|c|c|c|}
\hline & $\begin{array}{l}\text { moit } \\
\text { pasa }\end{array}$ & Fusutiony & recurbonas & $\operatorname{Prosplet}_{1}^{m}$ & $\min$ & montives \\
\hline $\sin _{100}$ & noconten: & 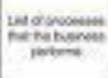 & ingen & - & 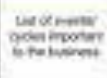 & nom \\
\hline 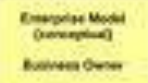 & (4) & 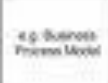 & 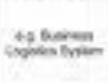 & " nombit: & 20 & "Nomen \\
\hline onsent & $*$ nos & 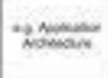 & of teresono & minem & "thom & 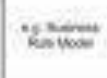 \\
\hline 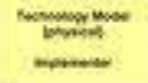 & 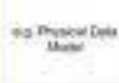 & $+2 \ln x$ & and & 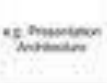 & 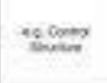 & $44 \mathrm{kentans}$ \\
\hline 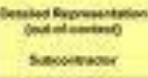 & $\cot 20$ & andor & $4 \pi \sin$ & And & $2 \tan 3$ & When \\
\hline 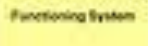 & 20000 & es krecose & eq & *4opmenom & as soresen & thom \\
\hline
\end{tabular}

Figure 2 The Zachman concept is represented in the form of a $6 \times 6$ matrix [5]

Based on the fact that currently PKU Muhammadiyah Gombong Hospital does not have a medical facility maintenance IS concept, EA at the conceptual level can be used as a list of identification of business functions in the scope of information technology (IT) [5]. In the case of the drafting of a medical facility maintenance IS concept, the EA design is expected to be in accordance with the following functions.

\subsection{Testing Functions}

The testing function carries out a process of physical examination and measurement to obtain the characteristics of medical devices so that information is obtained about ensuring the suitability of medical devices, work safety and specifications [6].

\subsection{Calibration Function}

The calibration function carries out a comparison process to ensure the relationship between the quantity shown by a measuring instrument or measurement system or the quantity immortalized on a measuring material and the actual quantity of the measured quantity. The purpose of this function is to get a value according to a predetermined standard.

\subsection{Inventory Function}

The inventory function carries out the function of collecting data on medical facilities. In this context the purpose of an inventory is defined as support for maintenance.

\section{METHODS}

The survey was conducted at the PKU Muhammadiyah Gombong Hospital using the method of observation and interviews with the Technician Team, the PSM Coordinator, the Head of the Public Facilities and Medical Facilities Section, the Hospital Facility Maintenance Installation Manager and the Director of Clinical Service Support. The survey variable is based on the 6 columns of the Zachman matrix for the scope of the Planner and Owner perspective.

Interview with stakeholders aims to obtain data about the scope, objectives, functions at the top level, executive policies, stakeholder involvement, the interrelationship between the scope and the cycle of each function that will be carried out. Furthermore, the data is validated using government policy formulations as outlined in the Regulation of the Minister of Health of the Republic of Indonesia Number 31 of 2018 concerning Applications, Infrastructure and Medical Devices [1]. The validated data is then entered into each column of the Zachman matrix as a result of the design of the contextual architecture of the medical facility maintenance business process.

The next stage is designing a business process concept based on the owner's perspective. This step is aimed at eliminating overlapped process functions, allocating new business processes, collaborating resources and eliminating ambiguities in medical facility maintenance procedures.

The final stage is to validate the design results to ensure that each checklist can be accepted by stake holders from the owner's perspective.

\section{RESULTS AND DISCUSSION}

The architectural design results will be described in two rows and six columns. The first line is a description from the planner's perspective and the second line is from the owner's perspective. 


\subsection{EA Design from a Planner Perspective}

The context of medical facilities maintenance has the main objectives, namely to improve the quality of clinical services, increase the accreditation status of the institution and improve resource efficiency. This context is defined as the matrix elements in the first row and first column (Why).

Improving clinical services can be successful if efforts are made to improve the quality of medical facilities and increase the competence of technical personnel. Improving the quality of medical facilities is strongly influenced by the maintenance process. The competence of technical personnel affects behavior and mindset in managing medical facilities (How).

Efforts to improve clinical services require material in the form of systematic and up to date medical facility maintenance data. Systematizing data will facilitate the presentation of information through applications. Updating data will provide factual and actual information (What).

The data that has been systemized and updated is very helpful for stakeholders in making decisions about the use and maintenance of medical facilities. Director of Support for Clinical Services, Hospital Facility Maintenance Installation Manager, Head of Section for Public and Medical Facilities, Coordinator of Maintenance of Medical Facilities, Coordinator of Maintenance of Medical Facilities carries out coordination functions with Medical Facility Technicians and Medical Facility Technicians who are technical maintenance of medical facilities. The commitment of the parties will determine the success of the medical facility maintenance process (Who).

Each level of stake holder is responsible for the maintenance of medical facilities in their respective scope. The Director of Clinical Service Support is responsible for the quality of clinical services in all units so that it requires assurance that medical facilities are in proper condition, the Hospital Facility Maintenance Installation Manager carries out the management function of medical facility management related to pre-installation to decommissioning activities. Coordination and the smooth flow of information between work units is needed in maintaining medical facilities (Where).

Events and triggers in the medical facility maintenance business process include preventive and corrective activities. This context is defined in the first row of the sixth column (When).

\subsection{EA Design From a Owner Perspective}

The success of the main objective is determined by the supporting objectives at the level below it. The definition of supporting objectives includes increasing the capacity of clinical services, increasing the capacity to use medical facilities, increasing the competence of human resources involved in the management of medical facilities and increasing the percentage of suitable medical facilities (Why).

Medical facility governance includes a process flow for the pre-installation, maintenance and removal of medical facilities. This element is the elaboration of the medical facility input process that produces clinical service outputs. Input fluctuation will affect the output volume (How).

Parties that interact with medical facilities consist of health workers and patients so that there is a correlation between the types of medical facilities, patient categories and user authorization as operators (What).

Geographically, the hospital consists of the location of outpatient wards, inpatient wards, polyclinics, sanitation, laboratories, pharmacies, emergencies and nutrition. This location forms a relationship model, namely the placement or installation of medical facilities. As a medical facility maintenance work unit, the PSM unit covers all clinical service units. Relations between units are formed based on the identification of the location of medical facilities (Who).

The location of the hospital in the district and in an integrated area provides the possibility to build a local network-based medical facility maintenance system architecture (Where).

In each clinical service work unit, there is a placement of medical facilities that have maintenance cycles that are preventive and corrective. The test and calibration scheduling function causes a preventive maintenance process flow. Damage reporting will result in a corrective maintenance process flow. The output of the preventive maintenance process flow can lead to a corrective maintenance process (When).

Validation is carried out by conducting interviews with stakeholders from director level to technical coordinator level. The validation process uses a definition checklist instrument for each element of the Zachman matrix. Respondents holding the position of Clinical Services Support Director were asked to provide comments on the suitability of the architectural definition against the main objectives and supporting objectives in the first column

Table 1. EA Design Validation Results

\begin{tabular}{|c|c|c|c|c|c|c|}
\hline & Why & How & What & Who & Where & Wher \\
\hline Contextual & $\sqrt{ } \sqrt{ }$ & $\sqrt{ } \sqrt{ }$ & $\sqrt{ } \sqrt{ }$ & $\sqrt{ } \sqrt{ }$ & $\sqrt{ } \sqrt{ }$ & $\sqrt{ } \sqrt{ }$ \\
\hline Conceptual & $\sqrt{ } \sqrt{ }$ & $\sqrt{ } \sqrt{ }$ & $\sqrt{ } \sqrt{ }$ & $\sqrt{ } \sqrt{ }$ & $\sqrt{ } \sqrt{ }$ & $\sqrt{ }$ \\
\hline \multicolumn{7}{|l|}{ Logical } \\
\hline \multicolumn{7}{|l|}{ Physical } \\
\hline Detailed & & & & & & \\
\hline
\end{tabular}


elements. Respondents who hold the Hospital Facility Maintenance and Installation Manager positions are asked to respond to the suitability of institutional policies and the definition of the medical facility management system.

The results of the validation on the design of the medical facility maintenance information system concept are presented in the form of a checklist in Table 1. Single check notation shows that the design results are acceptable but need to be analyzed and further discussed by the owner. The double check notation shows that the concept design results can be accepted with additional argumentative explanations. The triple checklist notation shows that the design results can be fully accepted.

\section{CONCLUSION}

The validation results show that the EA design can be fully accepted in the Why, How, What, Who and Where columns from the planner's perspective based on compliance with government regulations regarding the management of medical facilities and medical devices. From the owner's perspective, the When column cannot be fully accepted because it must first be analyzed several variables that affect the success of the medical facility maintenance process. The hypotheses that arise from the Owner about the variables include the life time of medical facilities that are included in the testing and calibration schedule, the demands and availability of new technology and financial factors.

\section{AUTHORS' CONTRIBUTIONS}

All authors contributed equally to this work.

\section{ACKNOWLEDGMENTS}

This research was supported and financed by the Electro-medical Technology Study Program of the Muhammadiyah University of Yogyakarta in collaboration with the PKU Muhammadiyah Gombong General Hospital in the apprenticeship program.

\section{REFERENCES}

[1] Kementerian Kesehatan, "Peraturan Menteri Kesehatan Republik Indonesia Nomor 31 Tahun 2018 tentang Aplikasi Sarana, Prasarana dan Alat Kesehatan,” Jakarta Kementeri. Kesehat., 2016

[2] Gao, Hongjie. Medical Equipment Maintenance under Modernized Management. 10.2991/msie-15.2015.90.

[3] Rogozov, Yury \& Belikov, Alexander \& Shevchenko, Oksana. The Approach to Basic Abstraction Construction for the Architectural Schemes Design. 10.2991/csit-19.2019.17.

[4] Prima Negara, Julius Galih \& Emanuel, Andi. A Conceptual Smart City Framework for Future Industrial City in Indonesia. International Journal of
Advanced Computer Science and Applications. 10. 10.14569/IJACSA.2019.0100762.

[5] Tim Weilkiens, Christian Weiss, Andrea Grass, Kim Nena Duggen, Chapter 7 - Frameworks, Editor(s): Tim Weilkiens, Christian Weiss, Andrea Grass, Kim Nena Duggen, OCEB 2 Certification Guide (Second Edition), Morgan Kaufmann, 2016, Pages 149-169, ISBN 9780128053522, https://doi.org/10.1016/B9780-12-805352-00007-8.

(http://www.sciencedirect.com/science/article/pii/B97 80128053522000078) Keywords: Process quality; Governance; Metric; Frameworks

[6] Direktorat Bina Pelayanan Penunjang Medik dan Sarana Kesehatan Kementerian Kesehatan Republik Indonesia, "Pedoman Pengelolaan Peralatan Kesehatan di Fasilitas Pelayanan Kesehatan," Jakarta Kementeri. Kesehat., 2015 